O AUTOR

Thiago de Mello

Nascido em 1926, na cidade de Barrerinha, interior do Amazonas, Thiago de Mello é autor de algumas das mais expressivas obras da literatura amazonense e brasileira. Iniciou seus estudos em Manaus, mas depois transferiu-se para o Rio de Janeiro, onde cursou até o quarto ano da Faculdade de Medicina. Dividido entre a arte poética e a ciência médica, optou pela primeira. Publicou seu primeiro livro Silêncio e palavra, em 1951. Thiago foi um dos intelectuais perseguidos pela ditadura militar de 1964 . Viveu um longo período no exílio, permanecendo no Chile até a derrubada do governo socialista de Salvador Allende. Entre suas obras, podemos destacar: Narciso cego (1952), Faz escuro mas eu canto (1965) e Os estatutos do homem (1977).

\title{
OS ESTATUTOS DO HOMEM ${ }^{1}$
}

\author{
(Ato Institucional Permanente)
}

A Carlos Heitor Cony

Artigo I

Fica decretado que agora vale a verdade agora vale a vida, e de mãos dadas, marcharemos todos pela vida verdadeira.

\section{Artigo II}

Fica decretado que todos os dias da semana, inclusive as terças-feiras mais cinzentas, têm direito a converter-se em manhãs de domingo. 


\section{Artigo III}

Fica decretado que, a partir deste instante, haverá girassóis em todas as janelas,

que os girassóis terão direito a abrir-se dentro da sombra; e que as janelas devem permanecer, o dia inteiro, abertas para o verde onde cresce a esperança.

\section{Artigo IV}

Fica decretado que o homem não precisará nunca mais duvidar do homem.

Que o homem confiará no homem como a palmeira confia no vento, como o vento confia no ar, como o ar confia no campo azul do céu.

Parágrafo único:

O homem confiará no homem como um menino confia em outro menino.

\section{Artigo V}

Fica decretado que os homens estão livres do jugo da mentira.

Nunca mais será preciso usar a couraça do silêncio nem a armadura de palavras. $\mathrm{O}$ homem se sentará à mesa com seu olhar limpo porque a verdade passará a ser servida antes da sobremesa.

\section{Artigo VI}

Fica estabelecida, durante dez séculos, a prática sonhada pelo profeta Isaías, e o lobo e o cordeiro pastarão juntos e a comida de ambos terá o mesmo gosto de aurora.

\section{Artigo VII}

Por decreto irrevogável fica estabelecido o reinado permanente da justiça e da claridade,

e a alegria será uma bandeira generosa para sempre desfraldada na alma do povo. 


\section{Artigo VIII}

Fica decretado que a maior dor sempre foi e será sempre

não poder dar-se amor a quem se ama

e saber que é a água

que dá à planta o milagre da flor.

\section{Artigo IX}

Fica permitido que o pão de cada dia tenha no homem o sinal de seu suor.

Mas que sobretudo tenha sempre o quente sabor da ternura.

\section{Artigo X}

Fica permitido a qualquer pessoa, qualquer hora da vida, uso do traje branco.

\section{Artigo XI}

Fica decretado, por definição, que o homem é um animal que ama

e que por isso é belo, muito mais belo que a estrela da manhã.

\section{Artigo XII}

Decreta-se que nada será obrigado nem proibido, tudo será permitido, inclusive brincar com os rinocerontes

e caminhar pelas tardes com uma imensa begônia na lapela.

Parágrafo único:

Só uma coisa fica proibida:

amar sem amor.

\section{Artigo XIII}

Fica decretado que o dinheiro não poderá nunca mais comprar o sol das manhãs vindouras. Expulso do grande baú do medo, o dinheiro se transformará em uma espada fraternal 
para defender o direito de cantar

e a festa do dia que chegou.

Artigo Final.

Fica proibido o uso da palavra liberdade, a qual será suprimida dos dicionários e do pântano enganoso das bocas.

A partir deste instante

a liberdade será algo vivo e transparente como um fogo ou um rio,

e a sua morada será sempre

o coração do homem.

Santiago do Chile, abril de 1964. 